\title{
The association of acrocentric chromosomes in 1000 normal human male metaphase cells
}

\author{
By MAIMON M. COHEN AND MARGERY W. SHAW \\ Division of Human Genetics, Department of Pediatrics, State University of New York at \\ Buffalo, Medical School. Buffalo Children's Hospital, Buffalo, New York \\ and Department of Human Genetics, University of Michigan Medical School, \\ Ann Arbor, Michigan \\ INTRODUCTION
}

Associations among the acrocentric chromosomes of man were first described by FergusonSmith \& Handmaker (1961) and Harnden (1961). Various investigators have suggested that such associations, in conjunction with other prominent heteropycnotic secondary constrictions, play a role in the organization of nucleoli (Schultz \& St Lawrence, 1949; Ohno et al. 1961; Hungerford, 1964; Ferguson-Smith, 1964). Participation of the acrocentric chromosomes in such associations has been postulated to increase the risk of non-disjunction with subsequent trisomic conditions of groups D and G (Harnden, 1961; Ferguson-Smith \& Handmaker, 1961). In fact, several families possessing chromosomally abnormal individuals have been purported to exhibit possible 'increased satellite association' (Tips et al. 1964; Kiossoglou et al. 1964; Lyons, Thompson \& Bigley, 1965; Zellweger, Abbo \& Cuany, 1966; Abbo, Zellweger \& Cuany, 1966). However, studies of this type have not been too well defined and in some cases both cytogenetically normal and abnormal individuals have been compared directly (Van Brink, Los \& Nienhaus 1962; Froland \& Mikkelsen, 1964; Bishun, 1966 ; Zellweger et al. 1966; Abbo et al. 1966). Such comparisons pose difficulties since the number of acrocentric chromosomes may not be the same in each case, e.g. trisomic and normal individuals. In addition, population data from a large series of normals on the frequency and distribution of satellite associations are meagre. In this paper, we present data on various aspects of satellite associations, in the hope that such results might form a basis for comparison between normal individuals and persons with abnormal cytogenetic constitutions.

\section{MATERIALS AND METHODS}

The population under investigation has been previously described in a study concerning variation in the length of the $Y$ chromosome (Cohen, Shaw \& MacCluer, 1966). The sample consists of ten cells obtained from each of 100 males drawn from five ethnic groups yielding a total of 1000 cells. These cells were originally selected for measurements of the $Y$ chromosome and in this respect, were totally unselected for the satellited elements. Only those cells with definitely identifiable $Y$ chromosomes were included in the study. The $Y$ chromosome, as well as those members of groups D, E, F, G and the no. 2 pair, were clearly marked on each photographic print. In the present study, therefore, the $Y$ chromosome could not be confused with an autosome of group $G$.

Parameters under investigation include: (1) the types and frequency distributions of associations among the satellited acrocentrics; (2) the association of the acrocentric chromosomes with 
the centrometric regions of non-acrocentrics; (3) association of the $Y$ chromosome with the satellited ends of the acrocentric chromosomes; (4) asymmetry in the length of the homologues of pair No. 2.

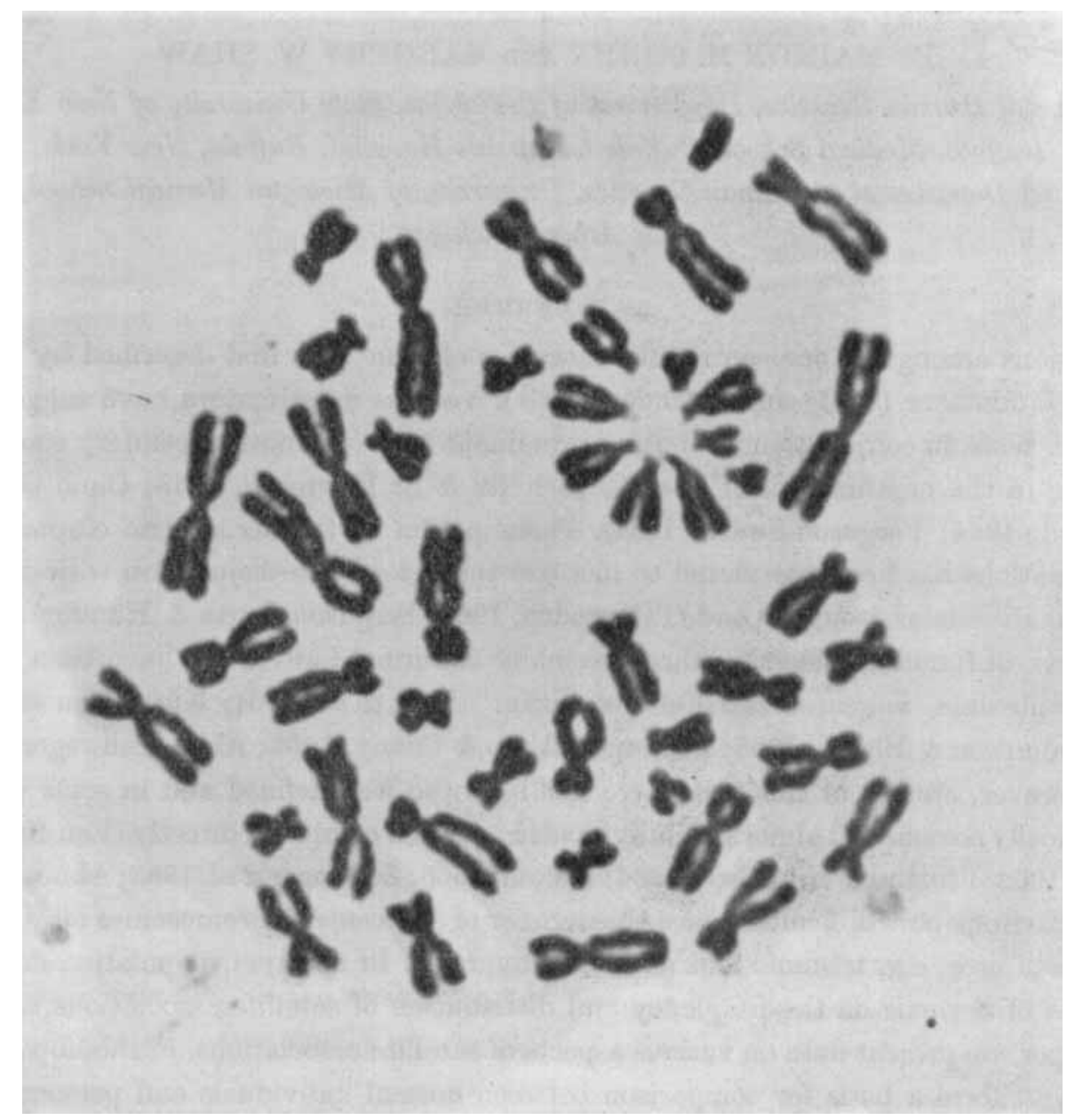

Fig. 1. A metaphase plate showing a multiple satellite association involving nine of the ten acrocentrics of the cell. This particular cell was not from the population under study.

The criteria which constituted an association were: (1) that the acrocentrics were oriented towards a common point by the satellited end, and (2) the distance between the satellited ends of the chromosomes was no greater than the length of the long arm of a group G chromosome in the particular cell under investigation. Figure 1 demonstrates a single association involving a group of nine acrocentrics in one cell. Each cell of the series was independently evaluated by both authors and only those associations agreed upon by both were included in the study. Data concerning the above parameters were obtained on the 1000 cells. This procedure allowed comparison of differences among individuals as well as among ethnic groups. 


\section{RESULTS}

Table 1 indicates the population values obtained for various parameters of association among the acrocentric chromosomes. The number of associations per cell, the number of chromosomes associated per cell, and the number of chromosomes per association showed no statistical differences among the individuals of an ethnic group, or among the five groups when tested by a nested analysis of variance considering the effects for individuals and ethnic groups as fixed (Steel \& Torrie, 1960). A chi-square analysis to test heterogeneity among ethnic groups for the number of D's and G's associated per cell also revealed no significant differences. Since no statistically significant differences were found among the estimates of these five parameters of acrocentric association, pooling of the data to yield population means and standard errors is justified (Table 1).

Table 1. Mean and standard error of various parameters of acrocentric association. Based on 1000 cells from 100 males of five ethnic groups.

\section{Parameter}

Number of associations per cell Number of chromosomes associated per cell Number of chromosomes per association Number of $\mathrm{D}$ chromosomes associated per cell Number of G chromosomes associated per cell

\section{Mean and standard error}

$$
\begin{aligned}
& 1.883 \pm 0.026 \\
& 4.465 \pm 0.060 \\
& 2.371 \pm 0.025 \\
& 2.450 \pm 0.062 \\
& 2.015 \pm 0.099
\end{aligned}
$$

An interesting relationship emerges between the number of $D$ and $G$ group elements associated per cell. If satellite associations occur in a completely random fashion, it would be expected that the number of $D$ to $G$ group chromosomes in these associations should conform to a ratio of $6: 4$. Such is not the case. From a total of 6000 possible D's, only 2450 or 0.4083 were found to be in associations while of the $4000 \mathrm{G}$ 's, 2015 or 0.5037 were associated. Therefore, from the present body of data, the empiric probability of an associated $\mathrm{G}$ is greater than that of an associated D chromosome in the ratio of $1.23 \mathrm{G}$ 's: $1 \mathrm{D}$ chromosome.

Each of the observed associations from the 1000 cells is listed in the Appendix according to various classes by the total number of chromosomes in the association. For example, class 0 contains cells with no associations, while class 7 contains those cells with a total of seven acrocentrics associated, irrespective of the number and types of associations per cell. Since under normal conditions, exclusive of autoradiographic procedures, neither the D nor the G chromosomes can be morphologically identified as individual elements, we must deal with only the combinations of associations, disregarding associations based on individual identity. This being the case, a total of 324 discrete cell patterns based on unique combinations of associations is possible.

Figure 2 illustrates the frequency distribution of the 1000 cells according to the number of chromosomes associated per cell. The shaded area depicts cells with only one association while the remainder of the histogram is determined by multiple associations per cell. It can be seen that no cell in this series contained a single association of more than six acrocentrics. The greatest tendency is to two chromosome associations. In only one cell were all ten acrocentrics associated; this cell contained four associations. Figure 3 describes the population of cells when classified according to numbers of associations per cell. Only thirty-four cells had no chromosomes associated, while the modal number of associations was two and no cell contained the theoretical maximum of five associations. 
It would be of great interest to ascertain whether or not acrocentric associations occur at random. An estimate of randomness can be gained by partitioning the several types of associations which occur in a class of specified size. It is possible for cells to contain the same total number of D's and G's associated in identical numbers of associations per cell, but yet exhibit

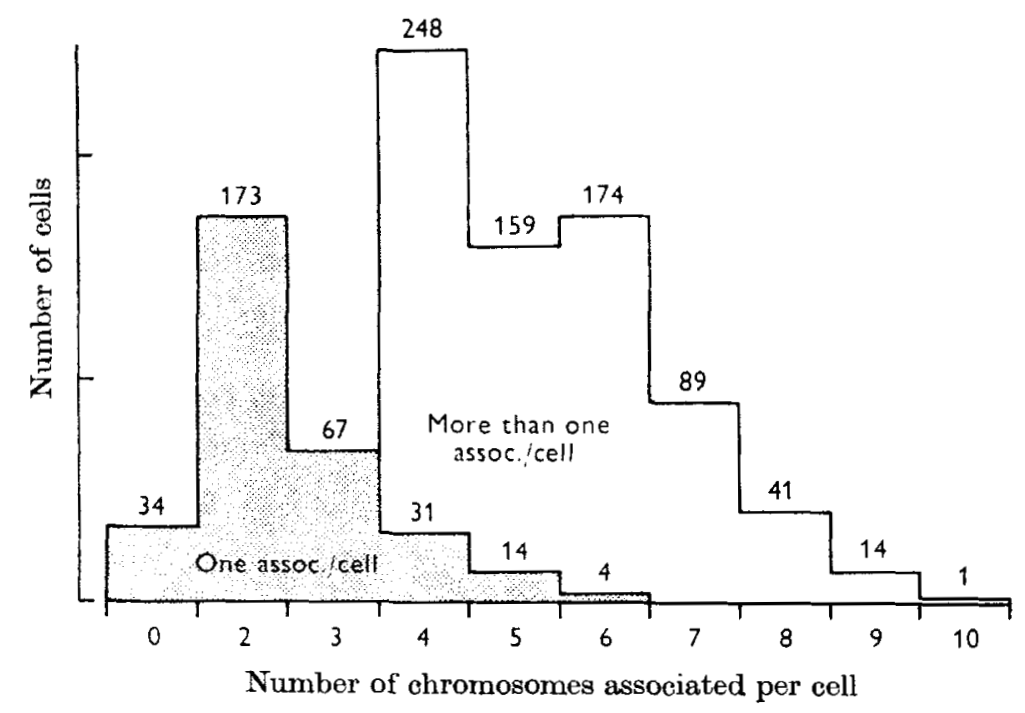

Fig. 2. The frequency distribution of the 1000 cells according to the number of chromosomes associated per cell.

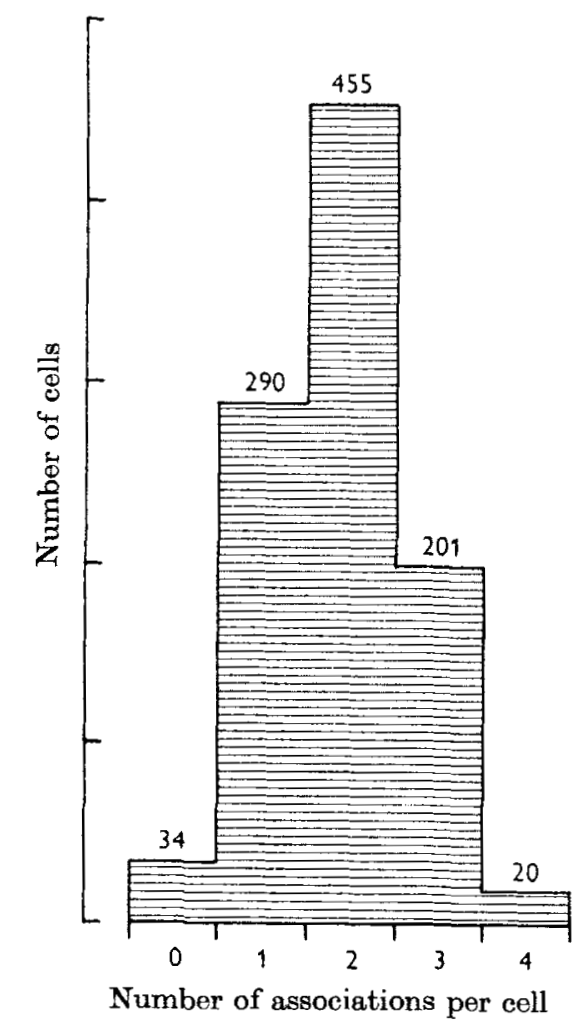

Fig. 3. The frequency distribution of the 1000 cells according to the number of associations per cell. 
different patterns of associations. For example, class 6 may have four D's and two G's associated in three groups of two-chromosome associations as $2 \mathrm{D}^{2}+\mathrm{G}^{2}$ or as $\mathrm{D}^{2}+2 \mathrm{DG}$. Table 2 lists some of those classes containing multiple association patterns; not all classes yielded sufficient data for analysis. However, among those classes tested, no deviation from randomness was observed. We may, therefore, conclude that if given the total number of $D$ and $G$ chromosomes in a specified number of associations, then the distribution of the chromosomes among the associations is random.

Table 2. Expected and observed proportions of some cells bearing the same number of associations and the same number of $D$ and $G$ chromosomes in associations but in different patterns

\begin{tabular}{|c|c|c|c|c|c|c|c|c|}
\hline Class & Groups & $\begin{array}{l}\text { No. } \\
\text { D's }\end{array}$ & $\begin{array}{l}\text { No. } \\
\text { G's }\end{array}$ & Comparison & $\begin{array}{l}\text { Expected } \\
\text { ratio }\end{array}$ & $\begin{array}{l}\text { Observed no. } \\
\text { of cells }\end{array}$ & $\chi^{2}$ & $P$ \\
\hline 4 & $2-2$ & 2 & 2 & $\left(D^{2}+G^{2}\right):(2 D G)$ & $I: 2$ & $36: 71$ & 0.008 & $0.95-0.90$ \\
\hline 5 & $3-2$ & 4 & $\mathbf{I}$ & $\left(D^{2} G+D^{2}\right):\left(D^{3}+D G\right)$ & $3: 2$ & 14: 10 & 0.028 & $0.90-0.80$ \\
\hline 5 & $3-2$ & 3 & 2 & $\begin{array}{l}\left(\mathrm{DG}^{2}+\mathrm{D}^{2}\right):\left(\mathrm{D}^{2} \mathrm{G}+\mathrm{DG}\right): \\
\left(\mathrm{D}^{3}+\mathrm{G}^{2}\right)\end{array}$ & $3: 6: 1$ & $23: 28: 6$ & $3 \cdot 176$ & $0.30-0.20$ \\
\hline 5 & $3-2$ & 2 & 3 & $\begin{array}{l}\left(G^{3}+D^{2}\right):\left(D G^{2}+D G\right): \\
\left(D^{2} G+G^{2}\right)\end{array}$ & $1: 6: 3$ & $7: 30: 17$ & 0.581 & $0.70-0.80$ \\
\hline 6 & $2-2-2$ & 4 & 2 & $\left(2 D^{2}+G^{2}\right):\left(D^{2}+2 D G\right)$ & I: 4 & $6: 32$ & 0.345 & $0.70-0.5^{\circ}$ \\
\hline 6 & $2-2-2$ & 3 & 3 & $\left(\mathrm{D}^{2}+\mathrm{DG}+\mathrm{G}^{2}\right):\left(3^{\mathrm{DG}}\right)$ & $3: 2$ & $28: 16$ & 0.024 & $0.80-0.70$ \\
\hline 6 & $4-2$ & 3 & 3 & $\begin{array}{l}\left(\mathrm{D}^{3}+\mathrm{DG}^{2}\right):\left(\mathrm{D}^{2} \mathrm{G}^{2}+\mathrm{DG}\right) \\
\left(\mathrm{DG}^{3}+\mathrm{D}^{2}\right)\end{array}$ & $6: 10: 3$ & $7: 10: 3$ & 0.015 & $>0.95$ \\
\hline 7 & $3-2-2$ & 4 & 3 & $\begin{array}{l}\left(D^{3}+D G+G^{2}\right):\left(D^{2} G+D^{2}+G^{2}\right): \\
\left(D^{2} G+2 D G\right):\left(D^{2}+D^{2}+D G\right): \\
\left(G^{3}+2 D^{2}\right)\end{array}$ & $3: 6: 12: 12: 1$ & $5: 4: 14: I 4: I$ & $I \cdot 97 \mathrm{I}$ & $0.80-0.70$ \\
\hline
\end{tabular}

Table 3. Association of the acrocentric chromosomes with centromeres of non-acrocentric elements and measurement of asymmetry between the homologues of the No. 2 pair

Figures in parentheses indicate percentage.

Acrocentric associated with centromere of:

\begin{tabular}{|c|c|c|c|c|c|c|c|c|c|c|c|}
\hline & No. I & No. 2 & No. 3 & $B$ & $C$ & $E$ & $F$ & Multiple & $Y$ & Total & Asymmetry of 2 \\
\hline Indians & I & 2 & 6 & 0 & 20 & 7 & 4 & 2 & $\begin{array}{c}12 \\
(6 \cdot 0)\end{array}$ & $\begin{array}{r}54 \\
\left(27^{\circ} 0\right)\end{array}$ & $0.941 \pm 0.046$ \\
\hline Japanese & 8 & 3 & 4 & 5 & 14 & 3 & I & 2 & $\begin{array}{c}10 \\
\left(5^{\circ} 0\right)\end{array}$ & $\begin{array}{r}50 \\
\left(25^{\circ} 0\right.\end{array}$ & $J .946 \pm 0.04 I$ \\
\hline Negroes & 8 & 5 & 2 & 6 & I I & 3 & 4 & 2 & $\begin{array}{c}\text { I I } \\
(5 \cdot 5)\end{array}$ & $\begin{array}{r}52 \\
(26 \cdot 0)\end{array}$ & $0.946 \pm 0.042$ \\
\hline Jews & 5 & 7 & 3 & 2 & 10 & 2 & 3 & 4 & $\begin{array}{c}8 \\
(4 \cdot 0)\end{array}$ & $\begin{array}{r}44 \\
(22 \cdot 0)\end{array}$ & $0.942 \pm 0.033$ \\
\hline Non-Jews & 8 & 8 & 4 & 9 & 13 & $\mathbf{r}$ & 5 & 3 & $\begin{array}{c}9 \\
(4.5)\end{array}$ & $\begin{array}{r}60 \\
(30.0)\end{array}$ & $0.946 \pm 0.039$ \\
\hline Population & $\begin{array}{c}30 \\
(3 \cdot 0)\end{array}$ & $\begin{array}{c}25 \\
(2 \cdot 5)\end{array}$ & $\begin{array}{c}19 \\
(1 \cdot 9)\end{array}$ & $\begin{array}{c}22 \\
(2 \cdot 2)\end{array}$ & $\begin{array}{c}68 \\
(6 \cdot 8)\end{array}$ & $\begin{array}{c}16 \\
(I \cdot 6)\end{array}$ & $\begin{array}{c}17 \\
(1 \cdot 7)\end{array}$ & $\begin{array}{c}13 \\
(1 \cdot 3)\end{array}$ & $\begin{array}{c}50 \\
(5 \cdot 0)\end{array}$ & $\begin{array}{c}260 \\
(26 \cdot 0)\end{array}$ & $\begin{array}{c}0.944 \pm 0.044 \\
\text { Coefficient of } \\
\text { variation }=4.6 \%\end{array}$ \\
\hline
\end{tabular}

Table 3 presents the data concerning the association of acrocentrics with centromeres of non-acrocentric chromosomes; the association of the $Y$ chromosome with the satellited acrocentries; and an estimate of the asymmetry between the members of pair no. 2. Association of the acrocentrics with the centromeric regions of non-acrocentric elements was present in $26.0 \%$ of the cells. The multiple associations refer to more than one acrocentric with a non-acrocentric centromere. The constancy of this phenomenon among the five groups is striking and no signifi- 
cant differences $\left(\chi^{2}\right.$ test: $\left.P>0 \cdot 10\right)$ were observed among the groups. Measurements obtained on the no. 2 chromosomes (Cohen et al. 1966) were used to estimate the asymmetry between these homologues. From the total of 1000 cells, 869 had both no. 2's which were adequate for measurement. A calculation of the $\frac{\text { total length of shorter no. } 2}{\text { total length of longer no. } 2}$ yielded a ratio indicating the length differences. An analysis of variance demonstrated no significant differences among the individuals within an ethnic group nor among the five ethnic groups. The ratio for the entire population was $0.944 \pm 0.044$ or an average length difference between the two homologues of $5.6 \%$ with a coefficient of variation of $4.6 \%$. In approximately $5.0 \%$ of the cells, the $Y$ chromosome appeared to be in association with the satellited end of an acrocentric.

\section{DISCUSSION}

A principle aim of this study was to establish baseline values for the phenomenon of satellite association in a normal population. The lack of significant statistical differences in the parameters presented in Table 1 indicates that perhaps in this population these characteristics of association may be constant. However, among other populations investigated, the results differ. Froland \& Mikkelsen (1964) studied 6458 cells and report that the number of satellite associations per cell was 1.32 and 0.49 for leukocytes and skin fibroblasts, respectively. An investigation by Bishun (1966) of 300 leukocyte metaphases yielded 0.88 associations per cell. At least three explanations for the diversity of these results are possible: (1) the criteria for defining an association are not uniform; (2) variation in culture techniques such as length of exposure to colchicine, fixation and slide preparation may cause differences in spreading of the chromosomes and dispersion of associations; and (3) investigators have included normal as well as abnormal individuals and the number of satellited chromosomes available for association may strongly influence the outcome of such studies. Therefore additional studies should be undertaken on normal populations following strictly defined criteria to establish these normal values.

From several other reports it appears that the $G$ group chromosomes are more frequently involved in associations than the D's. Reitalu (1964) states that the association frequencies of the D's and G's in 100 metaphases from normals were equal. Proportionally, therefore, the G's would tend to 'associate' more strongly since there are fewer of them. Van Brink et al. (1962) indicate that in cells from an $X O / X Y$ mosaic, those cells with 45 chromosomes, excluding the $Y$, demonstrated a statistically significant tendency for the G's to associate more strongly than the D's. Our data support these findings. However, it should be emphasized that this ratio was derived from the present data and remains to be tested by an independent investigation of additional normal cells, preferably from individuals of both sexes. If such a constant relationship does, indeed, exist, then testable predictions can be made concerning the frequency and types of satellite associations among individuals with abnormal karyotypes possessing more or less than ten acrocentrics, i.e. trisomics, $D / G$ or $G / G$ mongoloids and translocation carriers. Such studies are currently in progress and will be the subject of a subsequent paper.

Statistical analysis of the distribution of the chromosomes in the metaphase plate has been undertaken by several investigators (Schneiderman \& Smith, 1962; Miller et al. 1963a, $b$; Barton, David \& Merrington, 1964; 1965; Kowarzyk, Steinhaus \& Szymaniec, 1966a, b). The most common non-random aspect of such distributions is the tendency for the acrocentric chromosomes to associate by the satellited ends. This is an established cytological observation 
seen in every cytogenetics laboratory, but has been convincingly demonstrated statistically by Merrington \& Penrose (1964). However, detailed analysis of the types of associations seen among the ten elements is infinitely more complex. Irwin (1965) presents an analysis considering the associations within the $D$ and $G$ groups of chromosomes separately but not for all ten acrocentrics simultaneously. He intimates that satisfactory fits to his expected values are not obtained when all chromosomes are considered together because 'the probabilities of the A [G group] associations and the $D$ associations differ somewhat... and partly because the cross (AD) associations have a different probability from either'. One difficulty with Irwin's approach is the assumption 'that the probability of any pair being observed to be associated is $p$, and that this is the same for all pairs'. The fact that the fit is weak for associations involving more than two chromosomes in his analysis indicates that a second assumption may also fail; namely, 'that the probability of any single chromosome associated with any one group of already associated chromosomes is also $p$ - - the same probability as that of the initial two chromosomes associating. The relative differences in 'strengths' of association between the D and G chromosomes as demonstrated by our data as well as that of Van Brink et al. (1962) and Reitlau (1964), seem to negate the basic assumptions of Irwin's approach to the problem.

One difficulty in the analysis of this problem is the derivation of the expected values against which the observed distributions are to be tested. Ideally, these values should be theoretically determined, without resorting to the empiric data; however, such a derivation would demand knowledge of all the possible permutations of the acrocentric associations and the frequencies of each type. An obviously monumental undertaking! We had hoped to approach this problem by empirically deriving a relationship from the data and subsequent testing against the observed relative frequencies of association types. However, no apparent individual patterns emerged, possibly due to the small number of cells examined per person. Studies currently in progress, using at least 500 cells per person (both normals and abnormals), may allow discernment of association patterns. However, it can be stated that in associations of specified size, containing a given number of $\mathrm{D}$ and $\mathrm{G}$ chromosomes, the distribution of the types of associations appears random (Table 2).

The association of acrocentric chromosomes with non-acrocentric elements has been reported by Shaw (1961) and Edwards (1961). Table 3 illustrates the frequencies of acrocentric-nonacrocentric association for all groups of chromosomes. In contrast to the data of Shaw (1961) the frequency of no. 1 involvement in our sample was $3 \%$ as opposed to $31 \%$ in her small sample of thirty-two leukocyte metaphases which were derived from only two individuals, both of whom were females. This phenomenon was quite constant among the ethnic groups of our population with an average of $26 \%$ of the cells showing some acrocentric-non-acrocentric association (range $22-30 \%$ ). One surprising observation, however, is the apparent end-to-end association of the $Y$ chromosome and the acrocentrics. Such configurations were seen in $5 \%$ of the cells. Whether these are true associations or a chance positioning of the chromosomes in these metaphase cells is a moot question at present. All of the chromosomal associations described in this paper involve heterochromatic or heteropyenotic regions of the chromosomes. In this regard, the phenomenon of association may merely be an extension of non-homologous heterochromatic ectopic pairing as described in both drosophila and man (Profokyena-Belgovskaya, 1938; Slizynski, 1945; Ferguson-Smith \& Handmaker, 1961; Kaufman \& Iddles, 1963; Ferguson-Smith \& Handmaker, 1963). The amount of asymmetry between the two homologues 
of pair no. 2 is approximately $6 \%$ of the total length. This figure is almost identical with that found by both Lejeune and Patau (Lejeune, 1964).

Although the intent of this paper was to present data from which normal values for frequencies and distributions of satellite associations could be established, it is obvious that the problem is more complex than originally anticipated. Many obstacles remain to the ultimate solution of the problem, not the least of which is the theoretical derivation of the expected values when considering all ten acrocentrics together. The discrepancies among those studies already reported indicate the need for collection of additional data using uniform criteria and methods of analysis to elucidate some of the difficulties inherent in this problem.

\section{SUMMARY}

A population of 1000 metaphase cells was investigated for various parameters of satellite associations. In this population of 100 males, no statistically significant differences were observed among individuals within an ethnic group nor among the ethnic groups. There was a distinct tendency for the G chromosomes to be 'associated' more frequently than the D group elements $(1 \cdot 23 G: 1 D)$. In multiple associations of specified sizes with a given number of $D$ and $\mathrm{G}$ chromosomes, the types of associations appear to be random.

This project was supported in part by United States Children's Bureau Project No. 417 and United States Public Health Service grant GM 09252. We are grateful for the helpful discussions and statistical advice of Drs C. A. B. Smith, Charles Sing and Jean W. MacCluer.

\section{REFERENCES}

Abbo, G., Zellweger, H. \& Cuany, R. (1966). Satellite association (SA) in familial mongolism. Hel. Ped. Acta 21, 293.

Bamton, D. E., David, F. N. \& Merrington, M. (1964). The positions of the sex chromosomes in the human cell in mitosis. Ann. Hum. Genet. 28, 123.

Barton, D. E., David, F. N. \& Mernington, M. (1965). The relative positions of the chromosomes in the human cell in mitosis. Ann. Hum. Genet. 29, 139.

Brshrv, N. P. (1966). Association of human satellited chromosomes. Experientia 22, 223.

Cofien, M. M., Staw, M. W. \& MacCluer, J. W. (1966). Racial differences in the length of the human $Y$ chromosome. Cytogenetics $\mathbf{5}, \mathbf{3 4}$.

EDWards, J. H. (1961). Chromosomal association in man. Lancet ii, 317.

Fergtison-SMith, M. A. (1964). The sites of nucleolus formation in human pachytene chromosomes. Cytogenctics $3,124$.

Ferguson-Smith, M. A. \& Handmaker, S. D. (1961). Observations on the satellited human chromosomes. Lancet i, 638.

Ferguson-Smith, M. A. \& Handmaker, S. D. (1963). The association of satellited ehromosomes with specific chrornosomal regions in cultured human somatic cells. Ann. Hum. Genet. $27,143$.

Froland, A. \& Mikkeisen, M. (1964). Studies on satellite associations in human cells. Hereditas 52, 248.

Harnden, D. S. (1961). The chromosomes. In Recent Advances in Human Genetics, Ed. L. S. Penrose. Boston, Massachusetis. Little, Brown.

HuvGERFOnD, D. A. (1964). Observations on the morphology and behaviour of normal human chromosomes. In Mammalian Cytogenetics and Related Problems in Radiobiology. Eds. C. Pavan, O. Frota-Pessoa, and C. R. Caldas. New York: Pergamon Press.

InwiN, J. O. (1965). A theory of the association (overlap) of chromosomes in karyotypes, illustrated by Dr Patricia Jacobs' data. Ann. Hum. Genet. 28, 361.

Kavfuar, B. P. \& Iddles, M. K. (1963). Ectopic pairing in salivary gland chromosomes of Drosophila melanogaster. I. Distributional patterns in relation to puffing. Portugalae Acta Biol. Ser. A 8, 225.

Kiossoglot, K. A., Rosenbaum, E. H., Mrtus, W. J. \& Dameshek, W. (1964). Multiple chromosomal aberrations in a patient with acute granulocytic leukemia associated with Down's syndrome and twinning. Blood 24, 134. 


\section{Acrocentric chromosomes in 1000 normal human male metaphase cells}

Kowarzyk, H., Steinhaus, H. \& Szymanife, S. (1966a). Arrangement of chromosomes in human cells. II. Distribution in metaphase figures. Bull. Acad. Polonaise Sci. 14, 401.

KowarzyK, H., Steinhaus, H. \& Szymaniec, S. (1966b). Arrangement of ohromosomes in human cells. III. Distribution of centromeres and orientation of chromosomes in the metaphase. Bull. Acad. Polonaise Sci. 14, 541.

Lejedne, J. (1964). The study of gross chromosomal abnormalities. In Somatic Cell Genetics, Ed. R. S. Krooth, Ann Arbor, Michigan: The University of Michigan Press.

Lyons, R. B., Thompson, H. \& Bigley, R. H. (1965). The 'sticky chromosome' syndrome. Proc. Am. Soc. Hum. Genet. p. 25.

Merrington, M. \& Penrose, L. S. (1964). Distances which involve satellited chromosomes in metaphase preparations. Ann. Hum. Genet. 27, 257.

Mrller, O. J., MukHerJee, B. B., BREG, W. R. \& Gamble, A. VAN N. (1963a). Non-random distribution of chromosomes in metaphase figures from cultured human leucocytes. I. The peripheral location of the $\mathbf{Y}$ chromosomes. Cytogenetics 2, 14.

Mrller, O. J., Breg, W. R., Mukherjee, B. B., Gamble, A. Van N. \& Christakos, A. C. (1963 b). Nonrandom distribution of chromosomes in metaphase figures from cultured human leucocytes. II. The peripheral location of chromosomes 13, 17-18 and 21. Cytogenetics 2, 152.

OhNo, S., Trujillo, J. M., Kaplan, W. D. \& Kinosita, R. (1961). Nucleolus organizers in the causation of chromosomal anomalies in man. Lancet ii, 123.

Prokofyena-Belgovskaya, A. A. (1939). Inert regions in the inner part of the $\mathrm{X}$-chromosome of Drosophila melanogaster. Bull. Acad. Sci., USSR, 3, 360.

Reitalu, J. (1964). Some observations on the association of satellite chromosomes. Hereditas 52, 248.

SChneIderman, L. J. \& Smith, C. A. B. (1962). Non-random distribution of certain homologous pairs of normal human chromosomes in metaphase. Nature, Lond. 195, 1229.

Scholtz, J. \& St LAWRence, P. (1949). A cytological basis for a map of the nucleolar chromosome in man. J. Hered. 40, 31.

Shaw, M. W. (1961). Association of acrocentric chromosomes with the centromere region of chromosome No. 1. Lancet i, 1351.

Slizynski, B. M. (1945). Ectopic pairing and the distribution of heterochromatin in the $X$-chromosome of salivary gland nuclei of Drosophila melanogaster. Proc. Roy. Soc. B 62, 114.

Steel, R. G. D. \& ToRrIe, J. H. (I960). Principals and Procedures of Statistics with Specific Reference to the Biological Sciences. New York: McGraw.

Tips, R. L., Smith, G. S., Meyer, D. L. \& Perkins, A. L. (1964). Familial mosaicism of a chromosome 16 abnormality associated with multiple congenital anomalies. Am.J. Ment. Defic. 69, 330.

VAN Brink, J. M., Los, P. C. \& Nienhaus, A. J. (1962). Satellite associations and identification of the Y chromosome in man. Genetica 33, 45.

Zellweger, H., Авbo, G. \& Cuany, R. (1966). Satellite association and translocation mongolism. J. Med. Gen. 3, 186. 


\section{APPENDIX}

The distribution of the 324 possible types of cells containing associations of acrocentric chromosomes

No.

cells

Class o

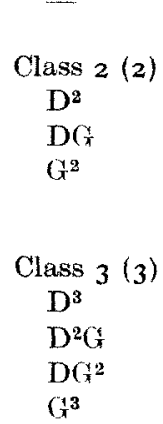

Class $4(4)$

$\mathrm{D}^{4}$

$\mathrm{D}^{3} \mathrm{G}$

$\mathrm{D}^{2} \mathrm{C}^{2}$

$\mathrm{DC}^{3}$

$\mathrm{C}^{4}$

$$
\begin{aligned}
& \text { Class } 4(2-2) \\
& 2 D^{2} \\
& D^{2}+D G \\
& D^{2}+G^{2} \\
& 2 D G \\
& D G+G^{2} \\
& 2 G^{2}
\end{aligned}
$$

Cláss 5 (5)

$D^{5}$

$\mathrm{D}^{4} \mathrm{G}$

$\mathrm{D}^{3} \mathrm{G}^{2}$

$\mathrm{D}^{2} \mathrm{G}^{3}$

$\mathrm{DC}^{4}$
Class 5 (3-2)
$\mathrm{D}^{3}+\mathrm{D}^{2}$
$\mathrm{D}^{3}+\mathrm{DG}$
$\mathrm{D}^{3}+\mathrm{C}^{2}$
$D^{2} G+D^{2}$
$\mathrm{D}^{2} \mathrm{C}+\mathrm{DG}$
$\mathrm{D}^{2} \mathrm{G}+\mathrm{G}^{2}$
$\mathrm{DG}^{2}+\mathrm{D}^{2}$
$\mathrm{DG}^{2}+\mathrm{DG}$
$\mathrm{DG}^{2}+\mathrm{G}^{2}$
$G^{3}+D^{2}$
$\mathrm{G}^{3}+\mathrm{DC}$

No.

cells

No.

cells

Class $7(5-2)$

$\mathrm{D}^{5}+\mathrm{DG}$

$\mathrm{D}^{5}+\mathrm{G}^{2}$

$\mathrm{D}^{4} \mathrm{G}+\mathrm{D}^{2}$

$\mathrm{D}^{4} \mathrm{G}+\mathrm{DG}$

$\mathrm{D}^{4} \mathrm{G}+\mathrm{G}^{2}$

$D^{3} G^{2}+D^{2}$

$D^{3} G^{2}+D G$

$D^{3} G^{2}+G^{2}$

$D^{2} G^{3}+D^{2}$

$\mathrm{D}^{2} \mathrm{G}^{3}+\mathrm{DG}$

$\mathrm{DG}^{4}+\mathrm{D}^{2}$

$D^{4}+\mathrm{DG}^{2}$

$\mathrm{D}^{3} \mathrm{G}+\mathrm{D}^{2}$

$\mathrm{D}^{3} \mathrm{G}+\mathrm{DG}$

$\mathrm{D}^{3} \mathrm{G}+\mathrm{G}^{2}$

$\mathrm{D}^{2} \mathrm{G}^{2}+\mathrm{D}^{2}$

$\mathrm{D}^{2} \mathrm{G}^{2}+\mathrm{DG}$

$\mathrm{D}^{2} \mathrm{G}^{2}+\mathrm{G}^{2}$

$\mathrm{DG}^{3}+\mathrm{D}^{2}$

$\mathrm{DG}^{3}+\mathrm{DG}$

$\mathrm{G}^{4}+\mathrm{D}^{2}$

Class $7(4-3)$

$\mathrm{D}^{4}+\mathrm{D}^{2} \mathrm{G}$

$\mathrm{D}^{4}+\mathrm{DG}^{2}$

$\mathrm{D}^{4}+\mathrm{G}^{3}$

$D^{3} \mathrm{G}+\mathrm{D}^{3}$

$\mathrm{D}^{3} \mathrm{G}+\mathrm{D}^{2} \mathrm{G}$

$\mathrm{D}^{3} \mathrm{G}+\mathrm{DG}^{2}$

$\mathrm{D}^{3} \mathrm{G}+\mathrm{G}^{3}$

$\mathrm{D}^{2} \mathrm{G}^{2}+\mathrm{D}^{3}$

$\mathrm{D}^{2} \mathrm{G}^{2}+\mathrm{D}^{2} \mathrm{G}$

$\mathrm{D}^{2} \mathrm{G}^{2}+\mathrm{DG}^{2}$

Class $6(3-3)$

$2 \mathrm{D}^{3}$

$\mathrm{D}^{3}+\mathrm{D}^{2} \mathrm{G}$

$\mathrm{D}^{3}+\mathrm{DG}^{2}$

$\mathrm{D}^{3}+\mathrm{G}^{3}$

$2 \mathrm{D}^{2} \mathrm{G}$

$\mathrm{D}^{2} \mathrm{G}+\mathrm{DG}^{2}$

$\mathrm{D}^{2} \mathrm{G}+\mathrm{G}^{3}$

${ }_{2} \mathrm{DG}^{2}$

$D^{3}+D^{3}$

$D^{3}+D^{2} G$

$\mathrm{G}^{4}+\mathrm{D}^{3}$

Class $7(3-2-2)$

$\mathrm{D}^{3}+\mathrm{D}^{2}+\mathrm{DG}$

$\mathrm{D}^{3}+\mathrm{D}^{2}+\mathrm{G}^{2}$

$\mathrm{D}^{3}+2 \mathrm{DG}$

$\mathrm{D}^{3}+\mathrm{DG}+\mathrm{G}^{2}$

$\mathrm{D}^{3}+2 \mathrm{G}^{2}$

$\mathrm{D}^{2} \mathrm{G}+2 \mathrm{D}^{2}$

Class $6(2-2-2)$

${ }_{3} \mathrm{D}^{2}$

$\mathrm{D}^{2} \mathrm{G}+\mathrm{D}^{2}+\mathrm{DG}$

$2 \mathrm{D}^{2}+\mathrm{DG}$

$2 D^{2}+G^{2}$

$\mathrm{D}^{2}+2 \mathrm{DG}$

$\mathrm{D}^{2}+\mathrm{DG}+\mathrm{G}^{2}$

3DG

$2 \mathrm{DG}+\mathrm{G}^{2}$

$\mathrm{D}^{2}+2 \mathrm{G}^{2}$

$\mathrm{D}^{2} \mathrm{G}+\mathrm{D}^{2}+\mathrm{G}^{2}$

$\mathrm{D}^{2} \mathrm{G}+2 \mathrm{DG}$

$\mathrm{D}^{2} \mathrm{G}+\mathrm{DG}+\mathrm{G}^{2}$

$\mathrm{DG}^{2}+2 \mathrm{D}^{2}$

$\mathrm{DG}^{2}+\mathrm{D}^{2}+\mathrm{DG}$

$\mathrm{DG}^{2}+\mathrm{D}^{2}+\mathrm{G}^{2}$

$D^{2}+2 D G$

$\mathrm{G}^{3}+2 \mathrm{D}^{2}$

$\mathrm{G}^{3}+\mathrm{D}^{2}+\mathrm{DG}$

Class 7 (7)

$\mathrm{D}^{6} \mathrm{G}$

$D^{5} G^{2}$

$D^{4} \mathrm{G}^{3}$

$D^{3} G^{4}$

Class 8 (8)

$\mathrm{D}^{6} \mathrm{G}^{2}$

$D^{5} G^{3}$

$\mathrm{D}^{4} \mathrm{G}^{4}$ \begin{tabular}{l}
0 \\
1 \\
0 \\
1 \\
3 \\
2 \\
4 \\
0 \\
1 \\
0 \\
2 \\
\hline 14
\end{tabular}

I

0

$\circ$

$\circ$

0

o

0

3

I

2

-

I

3

4

5

I

5

4

14
6

2

14

2

5

I

$\frac{1}{68}$

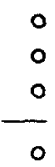


APPENDIX (cont.)

\begin{tabular}{|c|c|c|c|c|c|}
\hline & $\begin{array}{l}\text { No. } \\
\text { cells }\end{array}$ & & $\begin{array}{l}\text { No. } \\
\text { cells }\end{array}$ & & $\begin{array}{l}\text { No. } \\
\text { cells }\end{array}$ \\
\hline Class $8(6-2)$ & & Class $8(3-3-2)$ & & Class $9(5-4)$ & \\
\hline$D^{6}+G^{2}$ & $\circ$ & ${ }_{2} D^{3}+G^{2}$ & $\circ$ & $D^{5}+D_{G}^{3}$ & $\circ$ \\
\hline$D^{5} G+D G$ & ○ & $\mathrm{D}^{3}+\mathrm{D}^{2} \mathrm{G}+\mathrm{DG}$ & $\circ$ & $D^{5}+G^{4}$ & $\circ$ \\
\hline $\mathrm{D}^{5} \mathrm{G}+\mathrm{G}^{2}$ & $\circ$ & $\mathrm{D}^{3}+\mathrm{D}^{2} \mathrm{G}+\mathrm{G}^{2}$ & $\circ$ & $\mathrm{D}^{4} \mathrm{G}+\mathrm{D}^{2} \mathrm{G}^{2}$ & $\circ$ \\
\hline $\mathrm{D}^{4} \mathrm{G}^{2}+\mathrm{D}^{2}$ & $\circ$ & $D^{3}+D_{G}^{2}+D^{2}$ & o & $\mathrm{D}^{4} \mathrm{G}+\mathrm{DG}^{3}$ & $\circ$ \\
\hline $\mathrm{D}^{4} \mathrm{G}^{2}+\mathrm{DG}$ & $\circ$ & $\mathrm{D}^{3}+\mathrm{DG}^{2}+\mathrm{DG}$ & $\mathbf{r}$ & $\mathrm{D}^{3} \mathrm{G}^{2}+\mathrm{D}^{3} \mathrm{G}$ & o \\
\hline $\mathrm{D}^{4} \mathrm{G}^{2}+\mathrm{G}^{2}$ & $\circ$ & $\mathrm{D}^{3}+\mathrm{DG}^{2}+\mathrm{G}^{2}$ & $\circ$ & $\mathrm{D}^{3} \mathrm{G}^{2}+\mathrm{D}^{2} \mathrm{G}^{2}$ & I \\
\hline$D^{3} G^{3}+D^{2}$ & I & $D^{3}+G^{3}+D^{2}$ & o & $\mathrm{D}^{2} \mathrm{G}^{3}+\mathrm{D}^{4}$ & $\circ$ \\
\hline $\mathrm{D}^{3} \mathrm{G}^{3}+\mathrm{DG}$ & $\mathbf{I}$ & $\mathrm{D}^{3}+\mathrm{G}^{3}+\mathrm{DG}$ & ○ & $D^{2} G^{3}+D^{3} G$ & $\mathbf{I}$ \\
\hline \multirow[t]{4}{*}{$\mathrm{D}^{2} \mathrm{G}^{4}+\mathrm{D}^{2}$} & ० & $2 \mathrm{D}^{2} \mathrm{G}+\mathrm{D}^{2}$ & ○ & $\mathrm{DG}^{4}+\mathrm{D}^{4}$ & I \\
\hline & - & $2 D^{2} G+D G$ & 2 & & - \\
\hline & 2 & $2 D^{2} G+G^{2}$ & I & & 3 \\
\hline & & $\mathrm{D}^{2} \mathrm{G}+\mathrm{DG}^{2}+\mathrm{D}^{2}$ & 2 & Class $9(5-2-2)$ & \\
\hline Class $8(5-3)$ & & $\mathrm{D}^{2} \mathrm{G}+\mathrm{DG}^{2}+\mathrm{DG}$ & $\mathbf{I}$ & $\mathrm{D}^{5}+\mathrm{DG}+\mathrm{G}^{2}$ & $\circ$ \\
\hline $\mathrm{D}^{5}+\mathrm{DG}^{2}$ & $\circ$ & $\mathrm{D}^{2} \mathrm{G}+\mathrm{G}^{3}+\mathrm{D}^{2}$ & $\mathbf{I}$ & $\mathrm{D}^{5}+2 \mathrm{G}^{2}$ & $\circ$ \\
\hline$D^{5}+G^{3}$ & ० & $2 D^{2}+D^{2}$ & $\mathbf{I}$ & $\mathrm{D}^{4} \mathrm{G}+\mathrm{D}^{2}+\mathrm{G}^{2}$ & $\circ$ \\
\hline$D^{4} G+D^{2} G$ & o & & - & $\mathrm{D}^{4} \mathrm{G}+2 \mathrm{DG}$ & $\circ$ \\
\hline$D^{4} G+D G^{2}$ & $\circ$ & & 9 & $\mathrm{D}^{4} \mathrm{G}+\mathrm{DG}+\mathrm{G}^{2}$ & $\circ$ \\
\hline$D^{4} G+G^{3}$ & o & & & $\mathrm{D}^{3} \mathrm{G}^{2}+\mathrm{D}^{2}+\mathrm{DG}$ & $\mathbf{I}$ \\
\hline $\mathrm{D}^{3} \mathrm{G}^{2}+\mathrm{D}^{3}$ & ० & Class $8(2-2-2-2)$ & & $D^{3} G^{2}+D^{2}+G^{2}$ & $\mathbf{I}$ \\
\hline $\mathrm{D}^{3} \mathrm{G}^{2}+\mathrm{D}^{2} \mathrm{G}$ & I & ${ }_{3} \mathrm{D}^{2}+\mathrm{G}^{2}$ & $\circ$ & $\mathrm{D}^{3} \mathrm{G}^{2}+2 \mathrm{DG}$ & $\circ$ \\
\hline$D^{3} G^{2}+D G^{2}$ & $\circ$ & $2 D^{2}+2 D G$ & $\mathbf{I}$ & $\mathrm{D}^{2} \mathrm{G}^{3}+2 \mathrm{D}^{2}$ & $\circ$ \\
\hline$D^{2} G^{3}+D^{3}$ & $\circ$ & ${ }_{2} D^{2}+D G+G^{2}$ & 6 & $D^{2} G^{3}+D^{2}+D G$ & $\circ$ \\
\hline$D^{2} G^{3}+D^{2} G$ & 0 & $2 D^{2}+2 G^{2}$ & $\mathbf{I}$ & $D^{4}+2 D^{2}$ & $\circ$ \\
\hline \multirow[t]{4}{*}{$\mathrm{DG}^{4}+\mathrm{D}^{3}$} & $\circ$ & $\mathrm{D}^{2}+3 \mathrm{DG}$ & 3 & & 2 \\
\hline & - & $\mathrm{D}^{2}+2 \mathrm{DG}+\mathrm{G}^{2}$ & 4 & Class $9(4-3-2)$ & \\
\hline & $\mathbf{I}$ & ${ }_{4} \mathrm{DG}$ & $\mathbf{I}$ & $\mathrm{D}^{4}+\mathrm{D}^{2} \mathrm{G}+\mathrm{G}^{2}$ & o \\
\hline & & & 56 & $\mathrm{D}^{4}+\mathrm{DG}^{2}+\mathrm{DG}$ & o \\
\hline Class 8 (4-4) & & & I6 & $D^{4}+D^{2}+G^{2}$ & I \\
\hline $\mathrm{D}^{4}+\mathrm{D}^{2} \mathrm{G}^{2}$ & $\circ$ & & & $\mathrm{D}^{4}+\mathrm{G}^{3}+\mathrm{D}^{2}$ & 0 \\
\hline$D^{4}+D_{G}^{3}$ & $\circ$ & Class 9 (9) & & $D^{4}+G^{3}+D G$ & o \\
\hline$D^{4}+G^{4}$ & $\circ$ & $\mathrm{D}^{6} \mathrm{G}^{3}$ & $\circ$ & $\mathrm{D}^{3} \mathrm{G}+\mathrm{D}^{3}+\mathrm{G}^{2}$ & o \\
\hline $2 D^{3} G$ & 0 & $\mathrm{D}^{5} \mathrm{G}^{4}$ & 0 & $\mathrm{D}^{3} \mathrm{G}+\mathrm{D}^{2} \mathrm{G}+\mathrm{DG}$ & o \\
\hline$D^{3} G+D^{2} G^{2}$ & $\circ$ & & $\bar{E}$ & $D^{3} G+D^{2} G+G^{2}$ & 2 \\
\hline$D^{3} G+D G^{3}$ & 2 & & o & $\mathrm{D}^{3} \mathrm{G}+\mathrm{DG}^{2}+\mathrm{D}^{2}$ & o \\
\hline \multirow[t]{4}{*}{$2 \mathrm{D}^{2} \mathrm{G}^{2}$} & I & & & $D^{3} G+D G^{2}+D G$ & o \\
\hline & - & Class $9(7-2)$ & & $D^{3} G+G^{3}+D^{2}$ & ० \\
\hline & 3 & $\mathrm{D}^{6} \mathrm{G}+\mathrm{G}^{2}$ & o & $\mathrm{D}^{2} \mathrm{G}^{2}+\mathrm{D}^{3}+\mathrm{DG}$ & o \\
\hline & & $\mathrm{D}^{5} \mathrm{G}^{2}+\mathrm{DG}$ & $\circ$ & $D^{2} G^{2}+D^{3}+G^{2}$ & $\circ$ \\
\hline Class $8(4-2-2)$ & & $\mathrm{D}^{5} \mathrm{G}^{2}+\mathrm{G}^{2}$ & o & $D^{2} G^{2}+D^{2} G+D^{2}$ & $\mathbf{I}$ \\
\hline $\mathrm{D}^{4}+\mathrm{D}^{2}+\mathrm{G}^{2}$ & o & $D^{4} G^{3}+D^{2}$ & o & $D^{2} G^{2}+D^{2} G+D G$ & $\circ$ \\
\hline $\mathrm{D}^{4}+2 \mathrm{DG}$ & 0 & $\mathrm{D}^{4} \mathrm{G}^{3}+\mathrm{DG}$ & $\circ$ & $D^{2} G^{2}+D G^{2}+D^{2}$ & I \\
\hline $\mathrm{D}^{4}+\mathrm{DG}+\mathrm{G}^{2}$ & o & $\mathrm{D}^{3} \mathrm{G}^{4}+\mathrm{D}^{2}$ & o & $\mathrm{DG}^{3}+\mathrm{D}^{3}+\mathrm{D}^{2}$ & o \\
\hline $\mathrm{D}^{4}+2 \mathrm{G}^{2}$ & ० & & - & $\mathrm{DG}^{3}+\mathrm{D}^{3}+\mathrm{DG}$ & $\circ$ \\
\hline $\mathrm{D}^{3} \mathrm{G}+\mathrm{D}^{2}+\mathrm{DG}$ & $\mathbf{I}$ & & $\circ$ & $\mathrm{DG}^{3}+\mathrm{D}^{2} \mathrm{G}+\mathrm{D}^{2}$ & I \\
\hline $\mathrm{D}^{3} \mathrm{G}+\mathrm{D}^{2}+\mathrm{G}^{2}$ & I & & & $G^{4}+D^{3}+D^{2}$ & $\circ$ \\
\hline $\mathrm{D}^{3} \mathrm{G}+2 \mathrm{DG}$ & $\mathbf{I}$ & Class $9(6-3)$ & & & $\sqrt{6}$ \\
\hline $\mathrm{D}^{3} \mathrm{G}+\mathrm{DG}+\mathrm{G}^{2}$ & 2 & $D^{6}+G^{3}$ & $\circ$ & & \\
\hline $\mathrm{D}^{2} \mathrm{G}^{2}+2 \mathrm{D}^{2}$ & o & $D^{5} G+D G^{2}$ & $\circ$ & $\begin{array}{l}\text { Class 9 }(3-3-3) \\
2 D^{3}+G^{3}\end{array}$ & 0 \\
\hline $\mathrm{D}^{2} \mathrm{G}^{2}+\mathrm{D}^{2}+\mathrm{DG}$ & 2 & $D^{5} G+G^{3}$ & $\circ$ & & $\begin{array}{l}0 \\
0\end{array}$ \\
\hline $\mathrm{D}^{2} \mathrm{G}^{2}+\mathrm{D}^{2}+\mathrm{G}^{2}$ & ० & $\mathrm{D}^{4} \mathrm{G}^{2}+\mathrm{D}^{2} \mathrm{G}$ & $\circ$ & $\begin{array}{l}D^{3}+D^{2} G+D^{2} \\
D^{3}+D^{2} G+G^{3}\end{array}$ & $\begin{array}{l}0 \\
0\end{array}$ \\
\hline $\mathrm{D}^{2} \mathrm{G}^{2}+2 \mathrm{DG}$ & 2 & $\mathrm{D}^{4} \mathrm{G}^{2}+\mathrm{DG}^{2}$ & $\circ$ & $\mathrm{D}^{3}+\mathrm{D}^{2} \mathrm{G}+\mathrm{G}^{3}$ & 0 \\
\hline $\mathrm{DG}^{3}+2 \mathrm{D}^{2}$ & ० & $D^{3} G^{3}+D^{3}$ & $\circ$ & $\mathrm{D}^{3}+2 \mathrm{DG}^{2}$ & $\circ$ \\
\hline $\mathrm{DG}^{3}+\mathrm{D}^{2}+\mathrm{DG}$ & I & $D^{3} G^{3}+D^{2} G$ & $\circ$ & $3^{D^{2} G}$ & $\circ$ \\
\hline \multirow[t]{2}{*}{$G^{4}+2 D^{2}$} & 0 & $D^{2} G^{4}+D^{3}$ & $\circ$ & $2 \mathrm{D}^{2} \mathrm{G}+\mathrm{DG}^{2}$ & - \\
\hline & $\overline{10}$ & & o & & $\circ$ \\
\hline
\end{tabular}




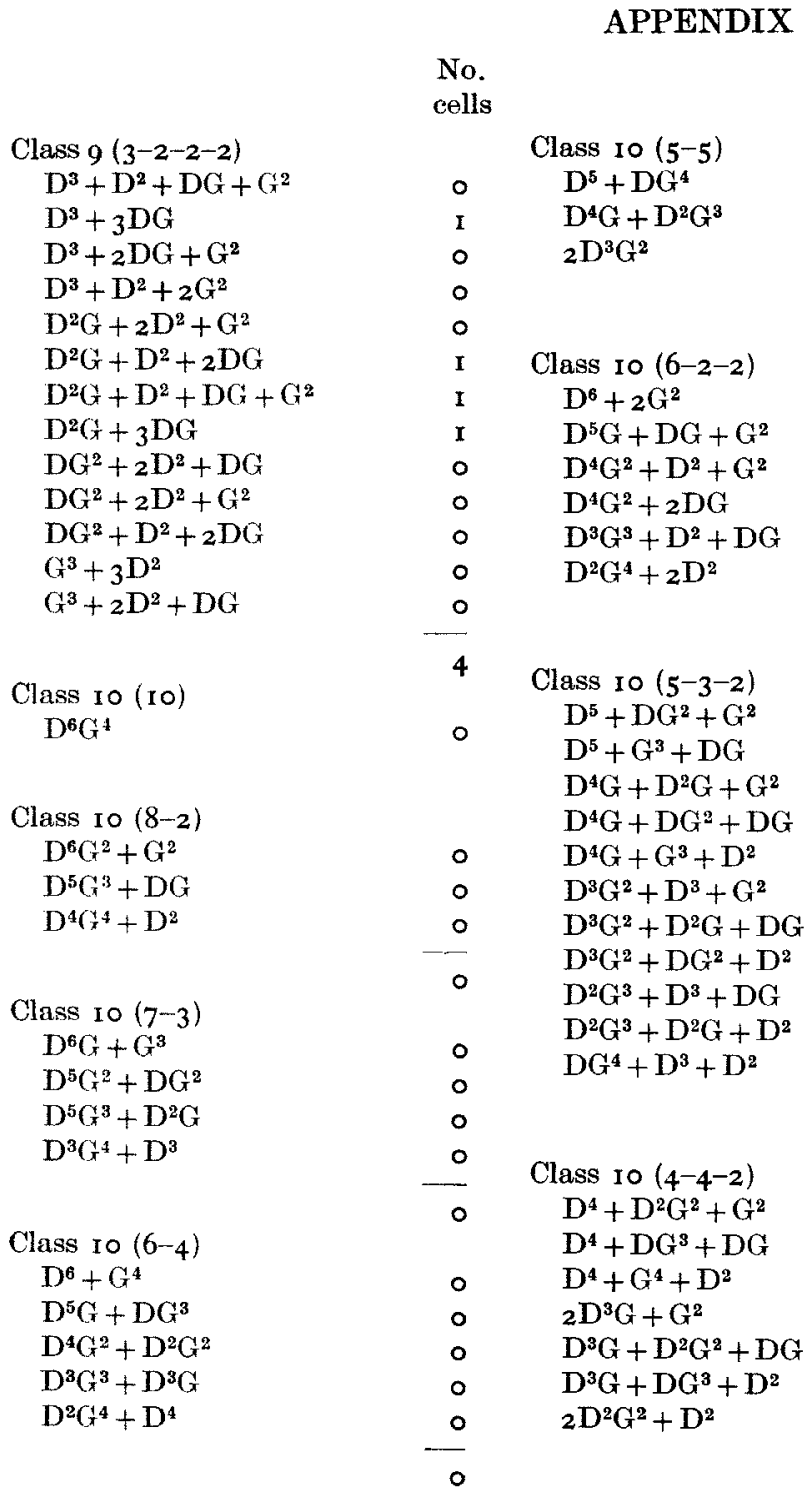

No.

cells

Class Io $(4-3-3)$

$\mathrm{D}^{4}+\mathrm{D}^{2} \mathrm{G}+\mathrm{G}^{3}$

$\mathrm{D}^{4}+2 \mathrm{DG}^{2}$

$\mathrm{D}^{3} \mathrm{G}+\mathrm{D}^{3}+\mathrm{G}^{3}$

$D^{3} \mathrm{G}+\mathrm{D}^{2} \mathrm{G}+\mathrm{DG}^{2}$

$\mathrm{D}^{2} \mathrm{G}^{2}+\mathrm{D}^{3}+\mathrm{DG}^{2}$

$\mathrm{D}^{2} \mathrm{G}^{2}+2 \mathrm{D}^{2} \mathrm{G}$

$\mathrm{DG}^{3}+\mathrm{D}^{3}+\mathrm{D}^{2} \mathrm{G}$

$\mathrm{G}^{4}+2 \mathrm{D}^{3}$

Class Io $(4-2-2-2)$

$\mathrm{D}^{4}+2 \mathrm{DG}+\mathrm{G}^{2}$

$\mathrm{D}^{4}+\mathrm{D}^{2}+2 \mathrm{G}^{2}$

$\mathrm{D}^{3} \mathrm{G}+\mathrm{D}^{2}+\mathrm{DG}+\mathrm{G}^{2}$

$\mathrm{D}^{8} \mathrm{G}+3^{\mathrm{DG}}$

$D^{2} G^{2}+2 D^{2}+G^{2}$

$D^{2} G^{2}+D^{2}+2 D G$

$\mathrm{DG}^{3}+2 \mathrm{D}^{2}+\mathrm{DG}$

$\mathrm{G}^{4}+3^{\mathrm{D}^{2}}$

Class ro $\left(3^{-3}-2-2\right)$

$2 \mathrm{D}^{2}+2 \mathrm{G}^{2}$

$\mathrm{D}^{3}+\mathrm{D}^{2} \mathrm{G}+\mathrm{DG}+\mathrm{G}^{2}$

$\mathrm{D}^{3}+\mathrm{DG}^{2}+\mathrm{D}^{2}+\mathrm{G}^{2}$

$\mathrm{D}^{3}+\mathrm{DG}^{2}+2 \mathrm{DG}$

$\mathrm{D}^{3}+\mathrm{G}^{3}+\mathrm{D}^{2}+\mathrm{DG}$

$2 D^{2} G+D^{2}+G^{2}$

$2 \mathrm{D}^{2} \mathrm{G}+2 \mathrm{DG}$

$\mathrm{D}^{2} \mathrm{G}+\mathrm{DG}^{2}+\mathrm{D}^{2}+\mathrm{DG}$

$\mathrm{D}^{2} \mathrm{G}+\mathrm{G}^{3}+2 \mathrm{D}^{2}$

$2 \mathrm{DG}^{2}+2 \mathrm{D}^{2}$

Class $10(2-2-2-2,-2)$

${ }_{3} \mathrm{D}^{2}+2 \mathrm{G}^{2}$

$2 \mathrm{D}^{2}+2 \mathrm{DG}+\mathrm{G}^{2}$

$\mathrm{D}^{2}+4 \mathrm{DG}$
No.

cells

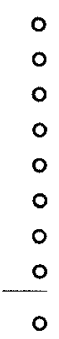

$\circ$

$\circ$

$\circ$

$\circ$

$\circ$

o

I

o

I

$\circ$

0

0

○

o

o

$\circ$

0

0

0

o

0

$\circ$

o 